\title{
黒緑豆タンパク質画分とその発芽過程における変化について
}

\author{
吉田 惠 子*, 四十九院 成子**, 福 場 博 保** \\ * 土浦短期大学 \\ *** 捕茶の水女子大学生活環境研究センター
}

\section{Fractions of Black Matpe Proteins and Their Changes during Germination}

\author{
Keiko YOSHIDA,* Shigeko TSURUSHIIN** and Hiroyasu FUKUBA** \\ *Tsuchiura Junior College, Tsuchiura, 300 \\ **Institute of Environmental Science for Human Life, Ochanomizu University, Bunkyo-ku, Tokyo, 112
}

Nippon Eiyō Shokuryō Gakkaishi (J. Jpn. Soc. Nutr. Food Sci.) 39, 415 421 (1986)

Storage protein in black matpe which is employed as a material for "Moyashi" (bean sprouts) was extracted and fractionated. The percentage of globulin ( $\mathrm{NaCl}$ soluble fraction) and albumin (water soluble fraction) was $70 \%$ and $28 \%$, respectively, of the total protein. Amino acid analyses of globulin and albumin indicated that two fractions had similar amino acid composition characterized by high contents of glutamic acid and asparatic acid and by extremely low contents of cysteine and methionine.

Crude globulin fraction was separated into four fractions $(\alpha, \beta, \gamma$ and $\delta$ ) by column chromatography on Sephadex G-150. $\beta$-Globulin (M.W., 160,000) was the main protein of the globulin. The $\beta$-globulin was eluted as one sharp peak by ion-exchange chromatography on a DEAE-Sepharose column. However, this peak was separated into three bands on polyacrylamide gel electrophoresis.

Following the germination, a gradual decrease in protein contents, and increase of soluble nitrogen and soluble amino acid were confirmed. The following changes were also observed for protein; the decrease of bands migrated to anode by polyacrylamide gel electrophorsis, the increase of bands of lower molecular weight's proteins by SDS-polyacrylamide gel electrophoresis, and the changes of elution profiles at lower molecular weight areas to be more broad by column chromatography on Sephadex G-150 and ion-exchange chromatography on DEAE-Sepharose.

(Received January 27, 1986)

豆科植物の種子は，一般にタンパク質含量が豊富で重 要なタンハク質の給源である。わが国でのもやしの原料 豆として大部分を占める黒緑豆もタンバク質含量が $22.8 \%$ とかなり多い。森1は, 黒緑豆もやしについて食 品学, 調理学, 商品学的に考察し, 近藤らは発芽過程で の中性脂質画分の変動 2 ， ステロール配糖体の変動 ついて, さらに山本4) らは発芽過程に打ける子葉タンパ ク顆粒の変化とアミラーセ活性について報告している。 しかしタンパク質含量が多いにもかかからず，黒緑豆の 眝藏タンパク質それ自体の研究はなされていない。著者 らはこれまでに，黒緑豆のプロテアーゼインヒビター5), ならびに黒緑豆のブロテフーゼ(7)にいいての研究を行 なってきた。今回はこれらの研究の一環として黒緑豆の

* ₹300 土浦市真鍋 6-7-10

** T112 東京都文京区大塚 2-1-1
貯蔵タンパク質の分析を試みた。

同時に黒緑豆の発芽体，すなわち黒緑豆むやしについ て発芽中の貯蔵タンパク質の变化についても検討した。 豆類の発芽過程でのタンパク質の変化については大豆発

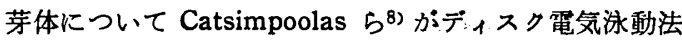
および免疫電気泳動法を用いて検討している。また，浅 野ら9)も，大豆について検討し日数経過とともにクロブ リンの $11 \mathrm{~S}$ 成分が隇少し低分子化していくことを示唆 している。緑豆むやしのタンパク質については皇山ら10) が報告しているか，その発芽中の変化については報告し ていない。豆の発芽過程での眝蔵タンパク質の変化をみ ることは植物体内でのタンバク質の分解，合成を明らか にするために不可欠のことであり，また酵素との関連な どもあわせて検討することができるのでたいへん興味潹 く種子の発芽機作解明に寄与するるのと思われる。同時 
に豆類の加工，眝蔵および調理の面でも重要な知見をる たらすものと考えられる。

\section{実 験 方 法}

\section{1. 実験材料}

黒緑豆 （ブラックマッヘ，Vigna mungo, 旧学名 Phaseolus mungo L. var radiatus Bak) はタイ国産の 輸入品をもやし業者を通じて購入した。電動ミルで粉砕 後 60 メッシュのふるいを通し粉末試料とした。原料豆 の一般成分は水分 $10.5 \%$ ，タンパク質 $22.8 \%$ ，脂質 $1.8 \%$, 炭水化物 $61.7 \%$, 灰分 $3.2 \%$ 1) であり, 四訂食 品成分表に示されている緑豆の成分値とは若干異なった 值である。

\section{2. あやしの発芽条件}

黒緑豆 $10 \mathrm{~g}$ を正確に秤取し水洗した後， $50^{\circ} \mathrm{C}$ の湯 浴中で 1 時間浸漬後 $24^{\circ} \mathrm{C}$ の恒温器中で適宜水を加えな がら発芽させた。発芽日数は $1,2,3,5,7$ 日の 5 種と した。

\section{3. 黒緑豆タンパク䓄および黑緑豆もやしタンパク留} の抽出, 分画方法

黒緑豆粉末試料およびむゃし試料に 6 倍量の $0.5 \mathrm{M}$ 塩 化ナトリウム溶液を加え室温で 1 時間䚌拌抽出し, $13,000 \mathrm{~g}$ で 10 分間遠心分離を行ない上澄液をタンパク 質溶液とした。また，タンパク質の分画は Chen and Bushuk の方法"11kよった。

\section{4. タンパク量, 總空素および可溶性空素量の 測定}

各画分抽出液中およびもやし抽出液のタンパク質量 は, ウシ血清アルブミン(NBC)を標準タンパク質として Lowry ら ${ }^{12)}$ の方法に従って求めた。総窒素量はミク口 ケルダール法13)を用いて測定した。可溶性窒素について は $10 \%$ トリクロール酢酸（TCA）をタンパク質溶液の $1 / 2$ 量加之 30 分放置後, $13,000 \mathrm{~g}$ で 10 分間遠心分離 を行ない上澄液について可溶性窒素量をミクロケルダー ル法13)にて測定した。また，カラム溶出液中のタンパク 質量については $280 \mathrm{~nm}$ の吸収から求めた。

\section{5. アミノ酸の定量}

Yemm and Cocking ${ }^{14)}$ のニンヒドリン法によって行 なった。

\section{6. アミノ酸分析}

日立 835 型アミノ酸自動分析機を用い分析しだ。加水

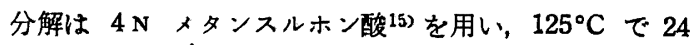
時間行なった。

\section{7. ゲルろ過およびイオン交換体}

あらかじめ $0.01 \mathrm{M} ト$ トスー塩酸緩衝液（pH 8.0）で 平衡化した Sephadex G-150 (Pharmacia) をカラム $(2 \times 51 \mathrm{~cm})$ に充填し， $19.5 \mathrm{ml} / \mathrm{hr}$ の流速で同緩衝液を
用いゲルろ過を行なった。またイオン交換体については DEAE-Sepharose イオン交換体（Pharmacia）を用い, $0.01 \mathrm{M} ト$ トス-塩酸緩衝液（pH 8.0）で平衔化後カラ 厶 $(1.6 \times 20.5 \mathrm{~cm})$ 飞充媜し試料を吸着させ，溶出は同 緩衝液中で食塩による直線濃度勾配法を用い，流速は $57.5 \mathrm{ml} / \mathrm{hr}$ とした。

\section{8. クロマトフォーカシング}

クロマトフォーカシング用に開発された Pharmacia 社の試薬を用いた。ポリバッファー交換体はPBE 94 を 用いた。開始ハッファーとして $0,025 \mathrm{M}$ イミダゾールー

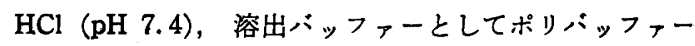
74- $\mathrm{HCl}(\mathrm{pH} \mathrm{4.0)}$ を用い, $\mathrm{pH}$ 勾配が 7 4 4なる条件 下で行なった。カラムサイズは $1.66 \times 10 \mathrm{~cm}$, 溶出速度 は $37.5 \mathrm{ml} / \mathrm{hr}$ とした。分画は $2.5 \mathrm{ml}$ とし UV モ= ターに接続して溶出液の $280 \mathrm{~nm}$ の吸光度を自記記録し た。

\section{9. 柴外部吸収スペクトルの㨽定}

ダブルビーム分光光電光度計 (島津製作所, UV180 型) とて紫外部吸收曲線を求めた。

10. ポリアクリルアミドゲル（PAG）ディスク電攻 泳動

Davis ${ }^{16)}$ の方法により 7.5\%，pH 9.4の PAGを調 製し室温で泳動した。

\section{SDS-ポリアクリルアミドゲル電気泳動}

Weber and Osborn'17) の方法に従い行なった。標準 タンパク質としてウシ血清てルブミン (M.W. 67,000, Pharmacia), 卵白アルブミン (M.W. 45,000, 生化学 工業), キモトリプシノーダン (M.W. 25,000, Sigma), チトクローム c (M.W. 12,500，三共）を用いた。

\section{実験結果扣よび考察}

\section{1. 黒緑豆タンパク監の分画}

予備実験により, $0.5 \mathrm{M}$ 塩化ナトリウム溶液でのタン バク質の抽出率が最も高かったのでこれを用いた。 Chen and Bushuk の方法代徒い溶解度の違いによる 分画を行なった。その結果を Table 1 に示した。各画 分のタンハクク質量比は水溶性画分（アルブミン画分）は

Table 1. Fractionation of black matpe protein.

\begin{tabular}{lcc}
\hline \hline Protein fraction & $\begin{array}{c}\text { Total } \\
\text { extracted } \\
\text { protein } \\
(\mathrm{mg})\end{array}$ & $\begin{array}{c}\text { Percent of } \\
\text { extractable } \\
\text { protein } \\
(\%)\end{array}$ \\
\hline Albumin & 494 & 27.6 \\
Globulin & 1,254 & 70.1 \\
Prolamin & 32 & 1.8 \\
Glutelin & 9 & 0.5 \\
\hline \hline
\end{tabular}


$27.6 \% ， 0.5 \mathrm{M}$ 塩化ナトリウム溶液可溶画分（グロブリ ン画分）は $70.1 \%$ であり全抽出タンパク質の $2 / 3$ 以 上を占めていた。

栽培植物の貯藏タンパク質のおもなものには，単子葉 植物である米に存在するクルテリン，あるいはとうもろ こしに存在するプロラミン，また双子葉植物である大 豆，小豆，アサなどに存在するグロブリンがある。大 豆 $^{18)}$, 小豆 ${ }^{19)}$ のロプリンについては詳細な研究がなさ れている。この黒緑豆の場合も主要タンパク質はグロブ リンであることが明らかになった。一方, 黒緑豆の場合 アルブミン画分も $28 \%$ とかなり存在しているのが特徵 的である。

\section{2. アミノ酸組成}

黒緑豆のタンパク質の大部分を占めるアルブミンとグ ロブリンについて検討し，結果を Table 2 に示した。 対照として森1) の報告している黑緑豆の全タンパク質の アミノ酸組成も掲げた。アルブミン，クロブリン，全タ ンハクク質ともその組成においては同様の傾向を示してい る。すなわちグルタミン酸，アスパラギン酸の含量が多 く，小麦20)などに比べ, リジン, アルギニンの含量が多

Table 2. Amino acid composition of albumin, globulin and black matpe protein. ${ }^{\text {a) }}$

\begin{tabular}{|c|c|c|c|}
\hline \multirow{2}{*}{ Amino acid } & \multicolumn{2}{|c|}{ Protein fraction } & \multirow{2}{*}{$\begin{array}{l}\text { Black } \\
\text { matpe } \\
\text { proteinb) }\end{array}$} \\
\hline & Albumin & Globulin & \\
\hline Lysine & 9.0 & 9.8 & 6.8 \\
\hline Histidine & 1.4 & 1.8 & 2.6 \\
\hline Arginine & 6.6 & 6.5 & 4.8 \\
\hline Aspartic acid & 12.6 & 11.8 & 10.8 \\
\hline Threonine & 6.0 & 2.3 & 3.9 \\
\hline Serine & 6.1 & 5.4 & 7.3 \\
\hline Glutamic acid & 15.1 & 16.6 & 17.9 \\
\hline Proline & 2.6 & 6.0 & 2.9 \\
\hline Glycine & 6.3 & 3.2 & 9.7 \\
\hline Alanine & 5.2 & 2.6 & 8.4 \\
\hline 1/2 Cystine & 0.8 & 0.3 & 0.2 \\
\hline Valine & 6.1 & 5.9 & 5.3 \\
\hline Metionine & 0.4 & 1.1 & 1.2 \\
\hline Isoleucine & 5.2 & 4.8 & 4.1 \\
\hline Leucine & 7.4 & 8.7 & 7.5 \\
\hline Tyrosine & 4.7 & 3.7 & 2.1 \\
\hline Phenylalanine & 4.6 & 9.5 & 4.4 \\
\hline
\end{tabular}

a) Tryptophan was not determined.

b) Data from Mori.1)
い。またプロリンは少なく含硫アミノ酸であるメチオニ ソ,システインも少ない。これは大豆1), 緑豆 ${ }^{1) な と ゙ と ~}$ 同じ傾向を示している。

\section{3. グロブリンの精製}

大豆グロブリンの精政においては超遠心分析が用いら れ沈降定数を異にする四成分 (2S，7S，11S，15S) が存 在することが確認され21)，ゲルろ過およびディスク焦点 電気泳動で得られた結果を比較しても同様な四成分の存 在が明らかにされている21)。そこで本実験では少量のサ ンプルで簡易にできる精製手段としてゲルろ過およびイ オン交換クロマトグラフィーを用いた。なおすべての操 作は $5{ }^{\circ} \mathrm{C}$ 以下で行なった。

1) Sephadex G-150 ゲルろ過 分画したグロブリン についてゲルろ過を行ない，同時に Andrews ${ }^{22)}$ の方法 に準じてゲルろ過による分子量の測定を行なった。その 結果, Fig. 1 に示すように四つの明膫なピークが認め られた。これを分子量の高い順に $\alpha, \beta, \gamma, \delta$ グロブリ ンとした。分子量を推定すると $\beta$ については 16 万程 度であった。また，おのおののピークについて紫外部吸 収スペクトルの測定を行なった。 $\alpha$ と $\beta$ は $280 \mathrm{~nm} に$ 最大吸収をもち典型的なタンパク質の性質を示したが， rと $\delta$ は $260 \mathrm{~nm}$ に最大吸収をもち核酸様物質の混在 も考えられた。これらのことより，グロブリンは前述の 四成分のらち $\alpha$ 画分と $\beta$ 画分とからなり，Fig. 1 に 示すよらにピークの大きさ，形などの点から分子量 16 万の $\beta$ 画分が主要成分と考えられた。

2) DEAE-Sepharose クロマトグラフィー ゲルろ

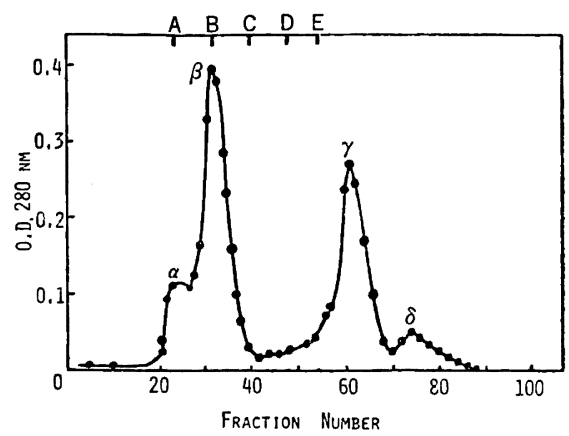

Fig. 1. Sephadex G-150 column chromatography of the black matpe globulin.

One $\mathrm{ml}$ of globulin $(26.4 \mathrm{mg}$ ) was applied on the column $(2 \times 51 \mathrm{~cm})$, equilibrated with $0.01 \mathrm{M}$ Tris- $\mathrm{HCl}$ butter ( $\mathrm{pH} \mathrm{8.0)}$, and eluted with the same buffer. The flow rate was $19.5 \mathrm{ml} / \mathrm{hr}$. A, blue dextran ; B, $r$-globulin (M.W. $=160,000$ ) ; C, bovine serum albumin (M.W. $=67,000) ; \mathrm{D}$, chymotrypsinogen $(\mathrm{M} . \mathrm{W} .=25,000) ; \mathrm{E}$, cytochrome c $(M . W .=12,500)$. 


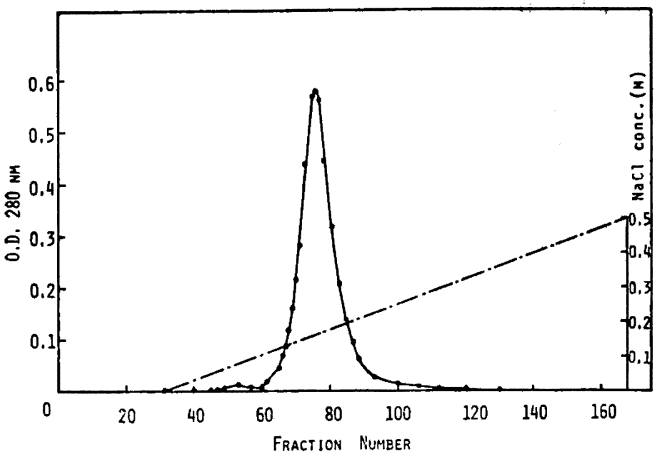

Fig. 2. DEAE-Sepharose ion-exchange chromatography of the $\beta$-globulin.

Sixty $\mathrm{ml}$ of the $\beta$-globulin fraction (fraction No. 30-37) obtained from Sephadex G-150 chromatography was applied on the column $(1.6 \times 20.5$ $\mathrm{cm}$ ), equilibrated with $0.01 \mathrm{M}$ Tris- $\mathrm{HCl}$ buffer (pH 8.0). The $\beta$-globulin was eluted at first with the same buffer and then a linear $\mathrm{NaCl}$ gradient from 0 to $0.5 \mathrm{M}$ in the same buffer. The flow rate was $57.5 \mathrm{ml} / \mathrm{hr}$.

過で得られた $\beta$ グロブリンを DEAE-Sepharose カラム によるイオン交換クロマトクラフィーに供した。食塩濃 度勾配は 0 0.5 M とした。その結果 Fig. 2 に示すよ らに食塩濃度 $0.17 \sim 0.22 \mathrm{M}$ 付近にシャープなピークが 溶出した。Fig. 1 と Fig. 2 の結果で示されたよらに $\beta$ グロブリンはクロマト的に単一のタンパク質よりなるも のとの推察も可能であるが，このタンパク質の均一性を 調べるためにディスク電気泳動を行なった。

3）ディスク電気泳動 粗グロブリンおよびおのおの の精製段階での $\alpha$ および $\beta$ グロブリンについてディス ク電気泳動を行ない,タンパク質の均一性を検討した (Fig. 3)。この結果, $\beta$ クロ ブリンは単一のタンパク質 よりなるのではなく多数のタンパク質の混合物であるこ とが明らかとなった。Fig. 3 の 4 の泳動図は DEAESepharose クロマトグラフィーで溶出したシャープな部 分である。カラムクロマトグラフィーにおいて単一と思 われたタンパク質も電気泳動的には 4 本のハンンドが認め られた。そこでさらに精製を行ならために以下の操作を 試みた。

4) DEAE-Sepharose 再クロマトグラフィー Fig. 2 に示したピーク部を集め, 食塩濃度勾配を $0.15 \sim 0.3$ M とゆるやかにして溶出を行なった。その結果を Fig. 4 に示した。Fig. 2 と同様 $0.17 \sim 0.22 \mathrm{M}$ 付近にシャ ーブなピークが溶出したが,このピーク部についてディ スク電気泳動を行なったところ，Fig. 3 の 5 に示した ようにパンドは明瞭になってきたものも3本覸察され

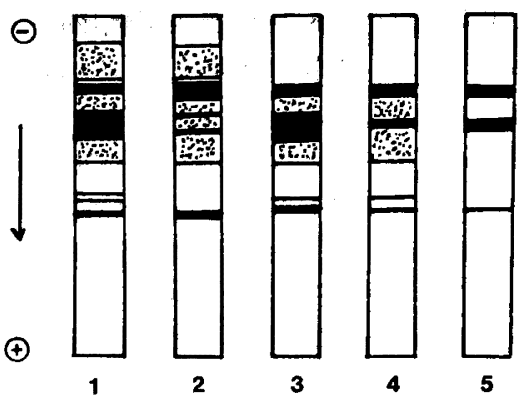

Fig. 3. Polyacrylamide gel electrophoresis of the black matpe globulin.

1 , Crude globulin ; $2, \alpha$-globulin (gel filtration) ; $3, \beta$-globulin (gel filtration); $4, \beta$-globulin (ion-exchange chromatography); $5, \beta$-globulin (second ion-exchange chromatography).

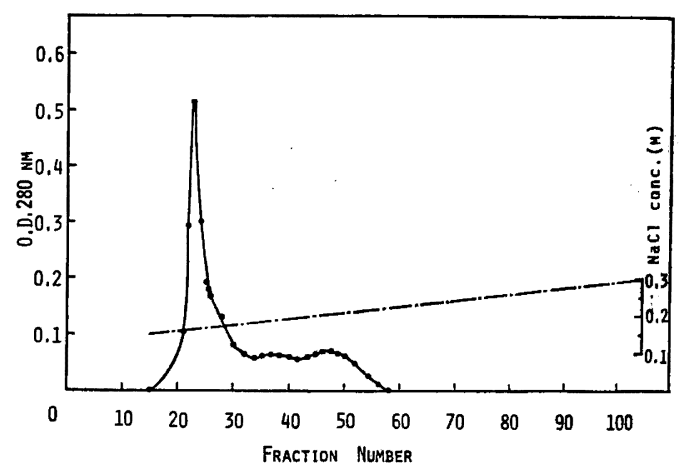

Fig. 4. Second DEAE-Sepharose ion-exchange chromatography of the $\beta$-globulin.

Twenty-three $\mathrm{ml}$ of the $\beta$-globulin fraction (fraction No. 71-82) obtained from DEAE-Sepharose ion-exchange chromatography. Linear $\mathrm{NaCl}$ gradient : $0.15-0.3 \mathrm{M}$. Detailed conditions were the same as those described in the legend to Fig. 2.

た。このことより $\beta$ グロブリンは 3 種のタンパク質より なることが明らかとなった。さらにこれら 3 種のタンパ ク質を単離するために次の操作を行なった。

5）クロマトフォーカシング Fig. 4 のピーク部を 集めクロマトフォーカシングを行なった。 $\mathrm{pH}$ 勾配 7 4 を用い溶出させたところ $\mathrm{pH} 5.15$ と $\mathrm{pH} 4.81$ に二つ のピークがみられた(Fig. 5)。さらに，おのおのピーク についてディスク䉓気泳動を行なったところ，前のピー クでは 3 本, 後のピークでは 2 本のハンドが観察され た。3種のタンバク質の分離はなされなかったが二つの ピークが溶出したことにより精製の手がかりを得たと考 えられる。今後よりいっそらの精製を試み，黒緑豆タロ ブリンの構成を明らかにする予定てある。 


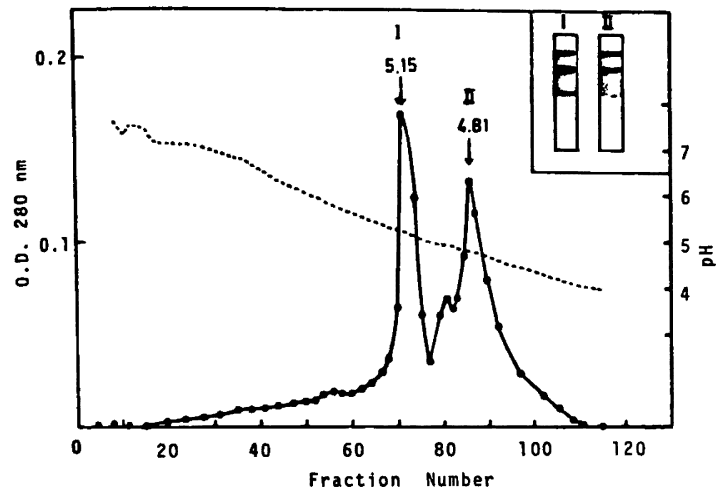

Fig. 5. Chromatofocusing of the $\beta$-globulin obtained from the 2 nd DEAE-Sepharose ion-exchange chromatography.

Ten $\mathrm{ml}$ of the sample (fraction No. 22-24) was applied on the column $(1.6 \times 10 \mathrm{~cm})$, equilibrated with starting buffer $(0.025 \mathrm{M}$ imidazole- $\mathrm{HCl}, \mathrm{pH}$ 7.4). Eluting buffer was polybuffer $74-\mathrm{HCl}(\mathrm{pH}$ 4.0). The flow rate was $37.5 \mathrm{ml} / \mathrm{hr}$.

\section{4. 黒緑豆もやしのタンパク澌について}

1）発芽過程での重量, タンパク質量, 総窒素量, 可溶 性窒素量および可溶性アミノ酸量の変化について

Fig. 6 に発芽日数ごとの標記の各値の变化を示した。 豆の重量は日数とともに水分を吸収し増加している。7 日目には $10 \mathrm{~g}$ の原料豆が総重量 $74 \mathrm{~g}$ となり 7.4 倍と なっている。一方タンパク質量は発芽とともに減少し とくに 3 日目に急激に減少している。総窒素量について みると発芽とともに減少はしているが 7 日発芽体におい ても未発芽のものに比べ 3 分の 2 は残っている。総窒素 量は豆が発芽体に変化しても量的には変わらないものと 予測したが，この減少は浸漬液中へ窒素の一部が流出し たものと思われる。

可溶性窒素量を示す非タンパク態窒素は発芽とともに 增加している。これは豆中の眝蔵タンパク質が発芽とと むに分解し可溶性窒素として遊離してきたためであろ 5。著者らのこれまでの研究において酸性プロテアーゼ 活性, カルボキシペプチダーゼ活性, アミノペプチダー ゼ活性がいずれも発芽 2 日目に最高の活性6)を示してい ることを考えあわせると，豆に水分が付与され組織の軟 化と膨潤により各酵素が発芽体のタンパク質に作用し分 解物としての可溶性窒素が多くなるものと推察される。

TCA 可溶画分中の窒素のかなりの部分はアミ/酸と して存在することが予想されるので可溶性アミノ酸量を 娜定したところ発芽とともに增加していた。これはタン ハク質がかなり急激に低分子化されてアミノ酸が增加し たものと考えられる。

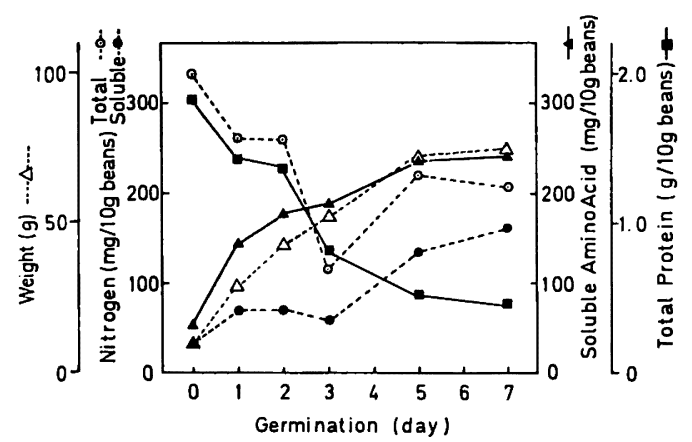

Fig. 6. Changes of weight, protein contents, total nitrogen contents, soluble nitrogen contents and soluble amino acid contents in black matpe during germination.

2）ディスク電気泳動 Fig. 7 に未発芽種子および 一定日数発芽させたもやしの全タンパク質の泳動写真を のせた。おのおのについてタンパク質を抽出し，タンパ ク質量として $100 \mu \mathrm{g}$ を用い泳動を行なった。未発芽種 子においてはタンパク質のバンドが数多く認められた。 発芽にともない中央部のハンドの变化はないが陽極側の ハンンドが減少した。Fig. 6 の結果とあわせて考学ると 貯蔵タンパク質が分解をうけ，量的に減少するととも に, タンパク質の構成成分が質的にも変化していくのが 示唆された。

また中央部の太いバンドについてみると，発芽中に多 少の変化をしているものの, つねに存在している。この ペントを Fig. 3 の泳動図と対応させるとグロブリンの 主成分と推定される $\beta$ 画分に相当するものと考兄られ る。このことより $\beta$ 画分は通常の発芽条件下では容易に 分解されないことが示唆された。著者らの行なった実験 に㧊いてこのタンパク質を酸性条件下で泳動させると酸 性プロテフーゼの作用によってこのバンドはすみやかに 減少していた23)。このことはさきに著者らが明らかにし た酸性プロテアーゼが貯蔵タンパク質の分解に関与して いるものと推察される。

3） SDS 電気泳動 次に発芽中のタンパク質の变化 について分子量的に検討した。前述のディスク電気泳動 での試料と同じものを調製し，量は一定 $(90 \mu \mathrm{g} / 150 \mu \mathrm{l})$ とした。すべてのゲルに分子量 67,000 と分子量 45,000 の間に太い:ンンドか存在し、このバンドがグロブリンを 構成するタンパク質の主成分と推察される。このように 前述のディスク電気泳動と同様グロブリンの主要なタン パク質は通常の発芽条件下では变化をらけないことが観 察された。また分子量 25,000 以下の低分子領域に発芽 にともない:ンドが增加していた。これはタンパク質が 発芽とともにプロテフーゼなどの作用をらけ低分子化す 


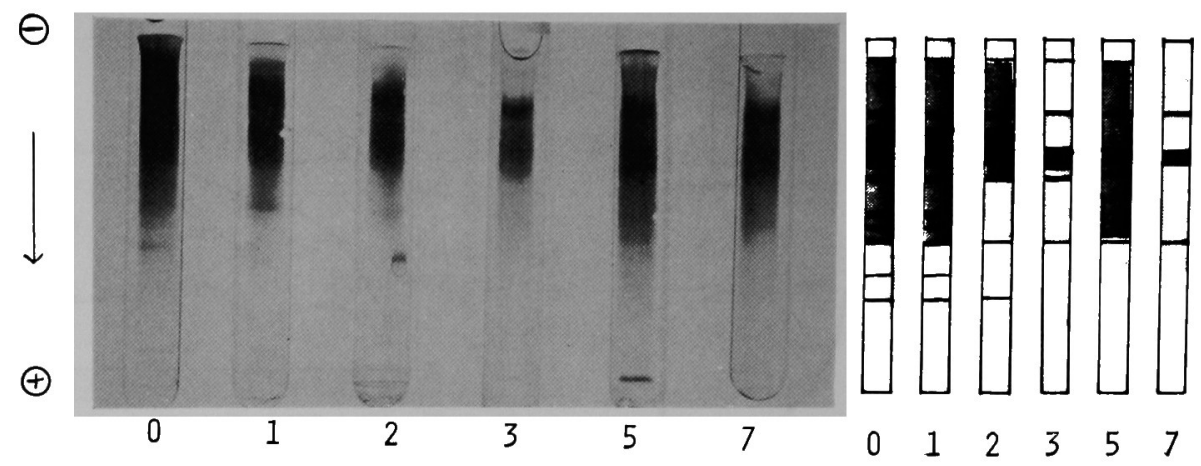

Fig. 7. Polyacrylamide gel electrophoresis of total black matpe proteins of ungerminated seeds ( 0 ) and of seeds germinated for a period of 1 day (1), 2 days (2), 3 days (3), 5 days (5) and 7 days (7).

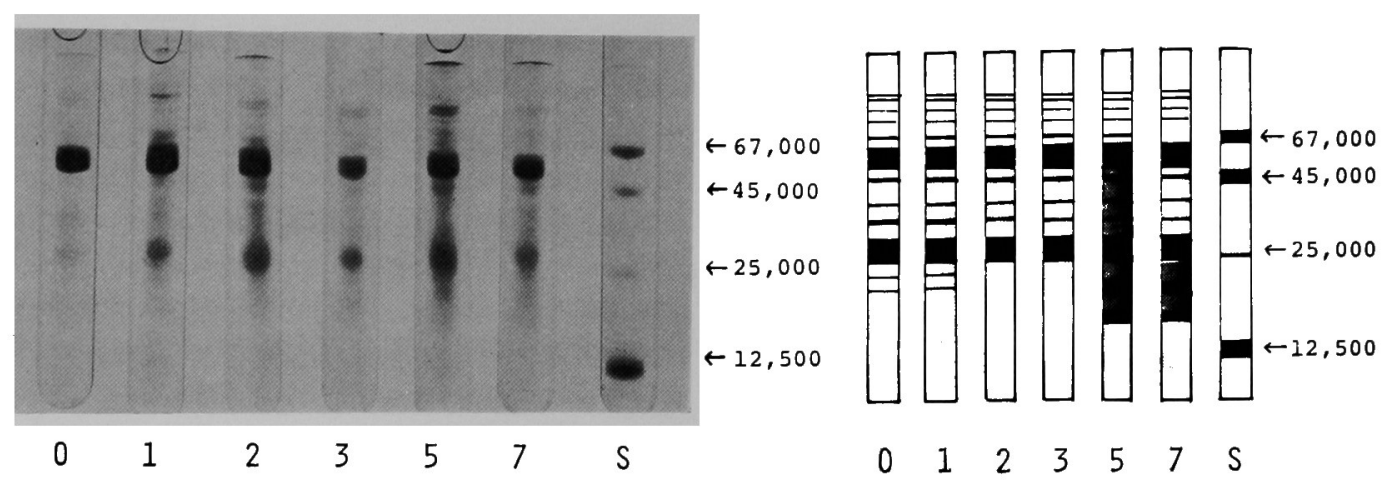

Fig. 8. SDS-polyacrylamide gel electrophoresis of total black matpe proteins of ungerminated seeds (0), and of seeds germinated for a period of 1 day (1), 2 days (2), 3 days (3), 5 days (5), 7 days (7) and standard proteins (S).

The standard proteins are bovine serum albumin $(M . W .=67,000)$, ovalbumin $(M . W .=4,5000)$, chymotrypsinogen (M.W. $=25,000)$ and cytochrome c $(M . W .=12,500)$.

るためと推察される。

4）ゲルろ過による変化 Fig. 9 に未発芽種子およ び一定日数発芽させたもやしの全タンパク質のゲルろ過 での溶出曲線を示した。上部に標準タンパク質の溶出位 置を示した。タンパク質量は未発芽種子， 1, 2, 3 日目 のもやしについては, $11.44 \mathrm{mg} / 4 \mathrm{ml}$ とした。 5,7 日 目のもやしについてはタンパク質濃度がうすく体積を一 定にしたためタンパク質量は少なく，5日目もやしは $4.88 \mathrm{mg} / 4 \mathrm{ml}, 7$ 日目もやしは $4.43 \mathrm{mg} / 4 \mathrm{ml}$ であった。 未発芽種子についてみると高分子量領域にも低分子量領 域にも二つずつのはっきりしたピークが認められる。発 芽にともない高分子量領域のピークは量的に減少してい る。また低分子量領域の質的な変化は顕著である。発芽 1 日目, 2 日目には二つのピークの存在は明らかである が 3 日目には肩のようになり 7 日目になるとピークは一 つになっている。これは発芽によりタンパク質が分解さ れ低分子化するとともに，さらに低分子のペプチド，ア
ミノ酸なども分解をらけ中間分子量のフラクションがピ ークとしてあらわれたものと思われる。

またこれらの試料についてイオン交換クロマトグラフ ィーを用いその变化を検討したところ, 未発芽種子にお いてはかなりはっきりしたピークが四つみられたが発芽 にともないそのピークは幅広くなることが観察された。 前述のディスク電気泳動, SDS 電気泳動, ゲルろ過で みられた現象と同じく貯蔵タンパク質が分解をらけ種々 のタンパク質, ペプチド, アミ, 酸が増加したためと思 われる。

本実験においては黒緑豆発芽体の全タンパク質につい ての変化を検討したが, 今後黒緑豆の主要タンパク質で あるグロブリンの精製を進めおのおのの画分についてよ り詳細な変化を検討し著者らが先に発表したインヒビタ 一, 各種プロテアーゼとの関連を調べ植物体内における 発芽とのかかわりあい等についても検討する予定であ る。 


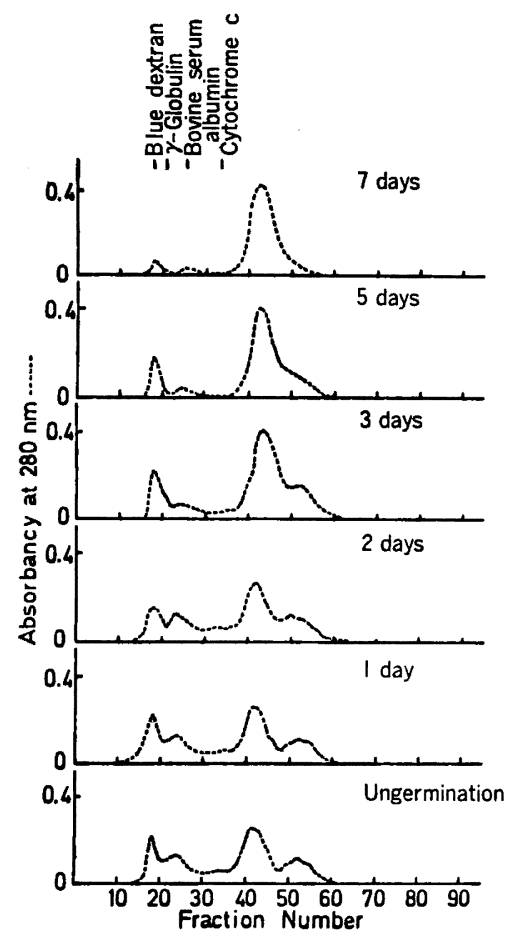

Fig. 9. Sephadex G-150 column chromatography of total black matpe proteins of ungerminated seeds and of seeds germinated for a period of 1 day, 2 days, 3 days, 5 days and 7 days.

Amounts of proteins applied : $11.44 \mathrm{mg}$ (ungermination, 1 day, 2 days, 3 days), $4.88 \mathrm{mg}$ (5 days), $4.43 \mathrm{mg}$ (7 days).

\section{要 約}

黒緑豆の眝蔵タンパク質およびその発芽体のタンパク 質について分析を試み以下のことが明らかとなった。

1）黒緑豆の貯蔵タンハク質の主要なるのはグロブリ ンであるがアルブミンもかなり存在しているのが特改的 である。

2) クロブリン，アルブミンのアミノ酸組成はグルタ ミン酸, アスパラギン酸が多くプロリン, メチオニン, システインは少なかった。

3）クロブリンを精製したところ，分子量 16 万のむ が主要なタンパ質でありここれは単一のタンパク質よ りのなるのではなく 3 種のタンパク質より成りたってい る。

4）豆の発芽体は日数とともにタンパク質含量が減少 し，可溶性窒素量および可溶性アミノ酸量が増加した。

5）発芽体のタンパク質の変化をディスク電気泳動,
SDS 電気泳動で調ぺたところ主たるタンパク質の変化 ははとんどみられなかったが，他のタンパク質は分解さ れディスク電気泳動においては陽極側のバンドが減少 し，SDS 電気泳動においては低分子量のバンドが増加 していた。

6）ゲルろ過，イオン交換クロマトグラフィーでその 変化をおらと発芽にともない両者ともピークがはっきり せず幅広いピークとなり低分子量のペプチド，アミノ酸 の増加が示唆された。

本研究の一部は第 38 回日本栄養・食䊓学会において 発表した。またこの研究は昭和 57 年度, 58 年度私学研 修福祉会の援助によって行なったものであり謝意を表し ます。

\section{文献}

1) 森 雅央：調理科学, 11, 167 (1978)

2) 近藤泰男 : 農化, 52,181 (1978)

3）近藤泰男, 増田和子, 黑岩千恵子 : 農化, 53,17 (1979)

4）山本知子，川上小つ总: 筑紫女学園短期大学 紀 要, 第 15 号別冊, 149 (1980)

5）四十九院成子, 吉田恵子, 福場博保 : 栄養と食糧, 32,321 (1979)

6）四十九院成子, 吉田恵子, 福場博保 : 栄養と食糧, 34, 373 (1981)

7）四十九院成子，福場博保 : 栄㙓之食糧，35，201 (1982)

8) Catsimpoolas, N., Cambell, T.G. and Meyer, E.W. : Plant Physiol., 43, 799 (1968)

9）浅野三夫, 柴崎一雄 : 食工誌, 20,126 (1973)

10）亀山真美, 増田 勉 : 家政学雑誌, 35, 370 (1974)

11) Chen, C.H. and Bushuk, W. : Can. J. Plant Sci., 50, 9 (1970)

12) Lowry, O.H., Rosebrough, N.J., Farr, A.L. and Randall, R.J. : J. Biol. Chem., 193, 265 (1951)

13) Horwitz, W. : Official Methods of Analysis of the Association of Official Analytical Chemists, 11th Ed., 858 (1970), Association of Official Analytical Chemists (Washington, D.C.)

14) Yemm, E.W. and Cocking, E.C. : Analyst, 80, 209 (1955)

15) Simpson, R.H., Neuberger, M.R. and Liu, T.-V. : J. Biol. Chem., 251, 1936 (1976)

16) Davis, B.J. : Ann. N.Y. Acad. Sci., 121, 404 (1964)

17) Weber, K. and Osborn, M. : J. Biol. Chem., 224, 4406 (1969)

18）越山育則：別冊蛋白質 核酸 酵素，456（1976）

19）田中 弘：家政学雑誌, 30,159 (1979)

20）製粉振興会 : 小麦一生産と利用一，150（1975）

21）越山育則, 福島男児: 栄炁之食䊓, 23, 297 (1970)

22) Andrews, P. : Biochem. J., 96, 595 (1965)

23）四十九院成子, 福場博保, 吉田恵子 : 第 39 回日 本栄堆·食糧学会総会講演要旨集, 153 (1985), (東京)

（昭和 61 年 1 月 27 日受理） 